\title{
POŽIŪRIO İ LAIKĄ IR DARBĄ DISKURSAS J. HABERMASO IR Z. BAUMANO DARBUOSE
}

\author{
Sonata Mačiulskytè \\ Klaipédos universitetas
}

\begin{abstract}
Anotacija
Jungtinių Tautų organizacijos paskelbtoje ataskaitoje „Human Development Report 2014“ skaičiuojant žmogaus socialinès raidos indeksą Lietuva 2014 m. tarp 187 valstybių pakilo ị 35 vietą. Tai geriausias rezultatas šalies istorijoje. Remiantis šiuo rodikliu, nuo $2010 \mathrm{~m}$. valstybė yra patekusi ị 49 labiausiai planetoje išsivysčiusių šalių „,klubą“. Vis dẻlto nepriteklius, lemiantis atitinkamas esmines socialinès diferenciacijos pasekmes, yra ịsitvirtinęs Lietuvos socialiniame diskurse. Siekdami suvokti oficialiosios statistikos ir gyvenimo realybès prieštaringumą, apie skurdą, nepriteklių ir socialinę atskirtị stereotipiškai mąstyti nebegalime. Šie socialiniai reiškiniai postmoderniame būvyje ịgauna naujų formų. Straipsnyje pristatomas dviejų socialinių kategorijų - laiko ir darbo, kurios iliustruoja mūsų socialinio gyvenimo dramatišką slinktị link postmodernaus būvio, suvokimo kaitos filosofinis aiškinimas J. Habermaso ir Z. Baumano darbuose. Socialinès laiko ir darbo kategorijos yra keletas tų socialinès-egzistencinès kaitos elementų, kurie atskleidžia aiškius modernybès ir postmodernybès filosofinių diskursų ir socialinès sąmonès skirtumus nuo ankstesnių filosofinės minties vystymo tradicijų. Šios kategorijos šiandien gali atskleisti naujas socialinès nelygybės formas.

PAGRINDINIAI ŽODŽIAI: modernizmas, postmodernus būvis, laikas, darbas.
\end{abstract}

\begin{abstract}
Lithuania has been placed $35^{\text {th }}$ out of 187 countries in the UNO Human Development Report 2014, which measures a Human Social Development Index. This is the best result in the history of the country. According to this indicator, since 2010, Lithuania has joined the club of 49 most developed countries in the planet. Despite the fact, poverty, which expresses the essential consequences of social differentiation, has deeply rooted in the social discourse of Lithuania. To understand the controversy of the official statistics and the reality of life, we can no longer think of poverty, deprivation and social exclusion stereotypically. These social phenomena are taking new shapes in the postmodern existence. Therefore, the article presents a philosophical explanation of the change in the perception of two social categories - time and work, which illustrate a dramatic shift of our social life towards the postmodern existence, based on the works of J. Habermas and Z. Bauman. Social categories of time and work are among the elements of social-existential change, which reflect clear differences of philosophical discourses and social consciousness of modernity and postmodernity from the earlier traditions of philosophical thought development. Today these categories acquire the power to reveal new forms of social inequality.
\end{abstract}

KEY WORDS: modernizm, postmodernizm, time, work.

DOI: http://dx.doi.org/10.15181/tbb.v68i3.889

\section{Ivadas}

Postmodernybės legitimacija yra vienas neblèstančių šiandienos intelektualų diskusijų objektų. Šių diskusijų rezultatai - daugybė postmodernybės ir jos tapsmo 
teorinių diskursų, publikuota knygų; šios magiškos sąvokos vartojimas peržengė uždarų intelektualų klubų ribas ir vis drąsiau taikomas kasdienei socialinei sąveikai aiškinti. Tačiau abejojančiujų ar neigiančiųų kokybiškai naujos filosofinès tradicijos atsiradimą netrūko postmodernybės užgimimo pradžioje, netrūksta jų ir dabar.

Postmodernybės teorijų yra daug ir ịvairių - nuo kokybiškai naujo filosofinio diskurso atsiradimo skelbimo iki (tik) naujo modernybės raidos etapo fiksavimo ar filosofinio kontrdiskurso (modernybei) idejos puoselèjimo. Vienas faktas yra akivaizdus - postmodernybès egzistavimas ontiškai susijęs su modernybės fenomenu. Postmodernybės tapsmo aiškinimas neatsiejamas nuo modernybès filosofinès tradicijos raidos analizès. Norint pažinti postmodernybės vystymo(si) motyvus ir teorines kryptis, būtina išsiaiškinti modernybès teorinę raidą. Kita vertus, bet kokio socialinio-filosofinio diskurso raida neatsiejama nuo konceptualizuoto kasdienio socialinio patyrimo atskleidimo.

Socialinès laiko ir darbo kategorijos yra keletas tų socialinės-egzistencinès kaitos elementų, kurie atskleidžia aiškius modernybės filosofinio diskurso ir socialinès sąmonès skirtumus nuo ankstesnių filosofinès minties vystymo tradicijų. Modernybė, be abejo, reiškẻ kokybiškai naują filosofinę koncepciją, inspiruotą visapusiško socialinio patyrimo sukurto intelektinio, technologinio, materialinio ir kito potencialo. Dèl to turbūt sutaria absoliuti dauguma socialinių mąstytojų.

Kalbant apie postmodernybės tapsmą, intelektualų pozicijos išsidèsto gana plačiame nuomonių spektre. Taip gali būti dèl šių priežasčių: pirma, nors intelektine postmodernybės pradžia laikomas XX a. vidurys, šios naujos vertybinès sistemos įsisąmoninimas, socialine praktika ir teorinis pagrindimas apibūdinami kaip vis dar esantys pradiniame (tačiau vis labiau ịsibègejjančiame) etape. Antra, reikia pastebèti, kad revoliucinių pokyčių socialinès sąmonès raidoje nefiksuojama. Tai kelia karštas diskusijas tarp naujos filosofinès tradicijos šalininkų, modernybės tęstinumo gynejų ir kontrdiskurso idejos puoselètojų. Šiandien sunku prognozuoti, kuri filosofinè postmodernybės vystymo kryptis išsikovos dominuojančią poziciją socialinès minties istorijoje; aišku tai, kad tokio (postmodernybės) klausimo kèlimas iš esmès žymi tam tikrą lūžị šiuolaikinès socialinės filosofijos raidoje. Tampa ịdomu modernybeje iš naujo ịvertinti tokias svarbias filosofines egzistencines vertybes kaip laikas ir darbas postmodernioje perspektyvoje.

Postmodernybès tapsmo aiškinimas igauna prasmę straipsnyje apribojus tyrimo aspektų imtị. Mokslininkai, kurių darbų pagrindu bus atliekama darbo ir laiko vertybių raidos lyginamoji analizè, pasirinkti neatsitiktinai ir yra nemenkas iššūkis šiam straipsniui. Jürgeno Habermaso ir Zygmundo Baumano socialinès teorijos vystymo strategijos šiek tiek skiriasi, kartu yra kažkuo panašios. Atliekant analizę remiamasi šiais jų darbais: J. Habermaso „Modernybės filosofinis diskursas“ (pirmojo leidimo metai - 1985 m.), Z. Baumano „Work, Consumerism, and the New 
Poor“ (pirmojo leidimo metai - 1999), „Globalizacija: pasekmės žmogui“ („Globalization: the Human Consequences“, pirmojo leidimo metai - 2000), „Liquid Modernity“ (pirmojo leidimo metai - 2000). Tai XX a. 9-10 dešimtmečių socialinių aktualijų kontekste užgimę darbai. Abu mąstytojai, tada jau priklausę dabarties socialinių mąstytojų elitui, plètodami savo intelektinę mintị iš esmès visiškai prasilenkia. J. Habermasas filosofinị tikrovès aiškinimą projektuoja iš modernybės vertybinių kostruktų i postmodernybès teorinị ir intelektinị pagrindimą. Kitaip sakant, postmodernybės jis ieško modernybès sukauptame teoriniame ir intelektiniame potenciale. Z. Baumano teorinė mintis - atvirkščiai, nukreipta priešinga kryptimi. Pagrindinis jo socialinès teorijos kūrimo objektas yra postmodernių būvių aiškinimas. Susidaro įspūdis, kad modernybę jis vertina iš postmodernios perspektyvos. Nepaisant jų galbūt beveik visiško teorinès minties plètojimo prasilenkimo, abiejų jų darbuose aiškinama laiko ir darbo suvokimo bei turinio kaita, tai padeda suprasti, kaip autoriai konstruoja modernybès ir postmodernybès socialines teorijas.

Tikslas: apmąstyti laiko ir darbo socialinių reiškinių suvokimo kaitos filosofinį aiškinimą, kaip postmodernybės tapsmo realumą J. Habermaso ir Z. Baumano intelektineje mintyje.

Objektas: laiko ir darbo sampratų raida J. Habermaso ir Z. Baumano darbuose.

Straipsnyje taikomas sisteminès analizès metodas, siekiant išsikelto darbo tikslo. Apibendrinimai pateikti išvadose.

\section{Naujo socialinio patyrimo atsivèrimas modernybės ir postmodernybès sandūroje}

Aiškinant postmodernios filosofinès tradicijos tapsmą J. Habermaso ir Z. Baumano darbuose būtina atsakyti ị keletą esminių klausimų. Pirmiausia, ką šie šiuolaikiniai mąstytojai vadina postmoderniu diskursu? Kokią poziciją jie užima aiškindami postmodernybės tapsmą? Koks jų postmodernybės aiškinimo istorinis-filosofinis išeities taškas? Kokius pagrindinius šiandienos socialinio patyrimo bruožus priskiria postmoderniam būviui? Atsakius ị šiuos klausimus, bus galima suformuoti teorinius šių mąstytojų postmodernybès tapsmo modelius, kurie padès išsamiau analizuoti paskiras postmodernybès tapsmo prielaidas jų darbuose.

J. Habermasas postmodernybès sampratą formuoja iš jo plètojamos istorinès filosofijos diskurso pozicijų. Postmodernybès tapsmą jo teorinèje koncepcijoje galima būtų išreikšti šiais pagrindiniais teiginiais:

1. Postmodernybès gimimą J. Habermasas sieja su modernios visuomenès socialinio patyrimo raida. Postmodernybės tapsmą mąstytojas aiškina modernybės ir jos savivokos, kuri atsiskleidžia racionalizme, atotrūkiu. Tai 
ìvardijama ir toliau savaime vykstančiu modernizacijos procesu terminu. J. Habermasas šią sąvoką aiškina savaime tebevykstančios visuomenès modernizacijos atsiskyrimu nuo tariamai absoliučiomis tapusių kultūros paskatu (Habermas, 2002, p. 11).

2. Remdamasis skirtingų mąstytojų teorinèmis nuostatomis, J. Habermasas suformuoja dvi postmodernybès tapsmo teorines-ideologines prielaidas:

- neokonservatyvų atsisveikinimą su modernybe J. Habermasui padeda suformuoti M. Weberio, J. Colemano, A. Gehleno ir kt. socialinès teorijos. J. Habermasas operuoja abstrahuotu M. Weberio modernybès sąvokos modernizacijos terminu, kuris nuo $\mathrm{XX}$ a. 6-ojo dešimtmečio reiškia gausejjančius ir vienas kitą stiprinančius procesus (kapitalo kaupimą ir išteklių mobilizavimą, gamybos jẻgų plètojimą ir darbo našumo kèlimą, t. t.), ir aiškina modernizaciją kaip savaime vykstanti procesą vystant apibendrintą laikui ir erdvei neutralių socialinių plètotès procesų modelį. Kitaip tariant, modernizacijos procesai suvokiami nebe kaip racionalizacija, o teoriniu evoliucijos požiūriu apibendrinta modernizacijos sąvoka nebesiejama su modernybès baigties ịvaizdžiu, taigi ir su tikslo pasiekimo būsena, kai turètu prasidèti postmodernybès raida. Šị sudètingą vidinių sąsajų tarp modernybės ir postmodernybès savivokos išnykimą $J$. Habermasas aiškina remdamasis A. Gehleno teorinėmis nuostatomis. Modernizacijai atliekant tik ekonomikos ir valstybès bei technikos ir mokslo funkcijas, nesustabdomas šių procesų greitèjimas išsekina kultūrinę visuomenès sriti, A. Gehlenas tai vadina šiuolaikinès kultūros kristalinimusi;

- anarchistinị pobūdị postmodernybès idèja ịgyja darbuose tų teoretikų, kurie nesutinka, kad yra prasidèjęs modernumo ir racionalumo atotrūkis. Anarchistinis atsisveikinimas su modernybe, kitaip nei neokonservatyvus, susijęs su modernybe kaip visuma. Racionalizmui prarandant savo moderniosios epochos jègą, ị socialinès filosofijos avansceną išeina protas: jis demaskuojamas kaip pavergiantis ir kartu pavergtas subjektyvumas, kaip valia ịgyti instrumento galią. Šiuo požiūriu visuomenès modernizacija negali pergyventi kultūros modernybès, iš kurios pati yra kilusi [M. Heidegerio, G. Batailleo teorinès nuostatos] (Habermas, 2002, p. 12).

Straipsnyje nagrinejami Z. Baumano darbai iš esmès neskirti postmodernybès sampratai aiškinti. Tai vienas žymiausių dabarties socialinių mąstytojų, dar vadinamas postmodernybès pranašu, darè ankstesniuose savo darbuose, tokiuose kaip 
„Postmodernybės užuominos“ („Intimations of Postmodernity“, 1992), „Postmodernioji etika“ („Postmodern Ethics“, 1993), „Gyvenimo fragmentai“ („Life in Fragments“, 1995), „Postmodernybė ir jos keliami rūpesčiai““(„Postmodernity and Its Discontents“, 1997) ir kt. Straipsnyje nagrinejjamus jo kūrinius galima apibūdinti kaip postmodernybės sampratos operacionalizavimą konkrečioms teorijoms plètoti. Nepaisant to, esminè jo teorinè nuostata konstruojant postmodernybès diskursą yra ta, kad Z. Baumanas istorinèje perspektyvoje postmodernybės laikotarpi vadina mūsu laikais. Tokio koncepto vartojimas atskleidžia jo filosofinès tradicijos konstravimo būdų artimumą J. Habermaso modernybès filosofinio diskurso kūrimo principams. Pastarasis mąstytojas, remdamasis G. W. F. Hegelio istorijos filosofijos periodizavimo modeliu, postmodernius laikus taip pat vadina naujausiais laikais.

Aptariant pagrindinius Z. Baumano socialinès teorijos konstravimo principus, reikia pastebėti, kad mąstytojas modernybès raidą aiškina, kaip ir savo socialinę teoriją konstruoja, remdamasis socialinio patyrimo raida. Šio mąstytojo teorines koncepcijas labiau būtų galima priskirti praktinès filosofijos sričiai: čia nėra tokių „sunkių“ teorinių konstruktų, kurie užpildo filosofijos istorijos turinį. Plètodamas straipsnyje nagrinèjamą socialinę teoriją, Z. Baumanas postmodernybès sąvoką operacionalizuoja skirtingais teoriniais aspektais:

- Teoriškai konstruodamas globalizacijos socialini turini postmodernią pasaulio tikrovę mąstytojas pateikia kaip pasaulị draskančio painumo ir didelių prieštaravimų idejją: postmoderniaja pasaulio tikrove jis laiko išreguliuoto / privatizuoto / vartotojiško bei globalizuojančio / lokalizuojančio pasaulio tikrovę, kuri tik labai blyškiai, vienpusiškai ir labai iškreiptai atskleidžiama postmoderniame pasakojime. Postmodernizmas - vienas iš daugelio galimų postmodernios tikrovès aiškinimų, tik išskleidžia kástini globaliųu [klasès] patyrimą, nepaaiškindamas ir neišreikšdamas kitų patyrimų, kurie taip pat būdingi postmoderniajai scenai (Bauman, 2002, p. 153-154).

- Teoriškai pagrịsdamas mūsų visuomenę, kaip vartotojų visuomenę, Z. Baumanas postmodernią socialinę patirtị apibūdina kaip visuomenès narių įtraukimą / vienijimą pirmiausia pagal jų, kaip vartotojų, sugebejjimus, taip, kaip moderni socialine patirtis suvienijo savo narius pirmiausia kaip gamintojus (Bauman, 2001, p. 76).

- Socialinès patirties moderniąsias teorines tradicijas Z. Baumanas skirsto ì „masyvią / sunkią modernybės“ (angl. solid / heavy modernity) epochą ir mūsų laikų „lakios / lengvos modernybės“ (angl. liquid / light modernity) periodą (Bauman, 2000). Tokị skirstymą mąstytojas grindžia kapitalizmo, kaip socialinio bendrabūvio istorinès formos, kaita nuo „sunkaus“ 
iki „lengvo“ kapitalizmo. „Lakios / lengvos modernybės“ koncepcija apima tokius šiandienos socialinio patyrimo bruožus, kaip lengvą kapitalo judejimą, darbo jẻgos lankstumo savybę gamybos santykiuose; momento akimirką, laiko, kaip atstumų ịveikimo mato, išnykimą ir erdvès „nuvertèjimą“ judant erdvejje ir pan. Teorinis skirtumas tarp „sunkiosios“ ir „lengvosios“ modernybès pasireiškia modernybès ,švelninančių jègų“ perskirstymu ir vietos pakeitimu, t. y. spaudimo jègų, suvaidinusių esmini vaidmeni (,sunkiosios") modernybės atsiradimo momentu, poveikio perorientavimu nuo „sistemos“ $i$, „visuomenę“ bei nuo „politikos“ srities $i$ „praktinès politikos" sferą; kitaip tariant, nusileidimu iš socialinio bendrabūvio makrolygmens ị mikrolygmenị (Ten pat, p. 6-7).

Postmodernybės teorijų išvystymo lygiai šiame straipsnyje nagrinèjamuose J. Habermaso ir Z. Baumano darbuose yra gana skirtingi, tačiau mąstytojai postmoderniam patyrimui priskiria analogiškas socialines charakteristikas:

- racionalizmą: nuo ekonominès technologinès modernizacijos iki savaime vykstančio visuomenès, kaip tokios, modernizacijos proceso;

- individualizmą: nuo asmeninès atsakomybès išsiplètimo visose žmogaus gyvenimo srityse iki privatizuotos modernybès ir pažangos.

Abu čia nagrinejjami mąstytojai - J. Habermasas ir Z. Baumanas - postmodernybės tapsmo aiškinimą grindžia istorine perspektyva ir modernybès savivokos prielaidomis. Postmodernybė yra modernaus socialinio patyrimo evoliucijos produktas, todèl jos gimimo prielaidų tikslinga ieškoti modernybès filosofiniame diskurse. Postmodernybès tapsmo prielaidoms aiškinti pasirenkama dviejų esminių socialinių modernybès gimimo aspektų - laiko ir darbo - raidos analizè. Šie socialiniai veiksniai gana išsamiai išplètoti ir J. Habermaso, ir Z. Baumano socialinėse teorijose; šių socialinių kategorijų kaitos analizè socialinio patyrimo raidos kontekste sudaro galimybę aiškinti modernybès ir postmodernybès atotrūkio bei postmodernybės tapsmo prielaidas.

\section{Naujos socialinės savivokos gimimas modernybės ir postmodernybès sandūroje}

\subsection{Laiko istorinis aktualizavimas}

Viena pagrindinių naujų socialinės nelygybės formų - laiko stoka. Kad šiandien būtum pripažintas skurstančiu, nebereikia badauti ar neturèti stogo virš galvos. I. Urbonaitė-Vainienė (2014) cituoja M. Mendelę-Leliugienę, kuri teigia: „Niekam ne paslaptis, kad jei nori išgyventi didmiestyje, turi suktis. Dèl to tèvai ne tik 
nebeturi laiko pabūti su savo vaikais, bet ir nebendrauja tarpusavyje“" (UrbonaitèVainienè, 2014).

Laikas yra subjektyvus socialinis reiškinys, nepaisant jo amžinumo ir objektyvios prigimties. Jis nuolat kinta ir nepriklauso nuo žmogaus valios, tačiau žmogui pavyko jị ịvaldyti ir suteikti konkretų socialinị vaidmenị. Būtent laiko socialinio patyrimo kaita siejama su modernybės eros užgimimu ir sklaida. Vèlyvajame modernybès diskurso etape patiriama nauja laiko suvokties socialinio vaidmens transformacija. Filosofinę laiko sampratos raidą J. Habermaso ir Z. Baumano socialinèse teorijose galima būtų periodizuoti tokia tvarka:

1. Ikimodernieji laikai - fatališka laiko ir erdvès tarpusavio priklausomybè.

2. Modernybès pradžia - laiko istorijos pradžia.

3. Postmodernybès tapsmas - laiko reikšmès išnykimas.

Iki pat modernybės - moderniujų laikų - filosofinio diskurso užgimimo egzistencinis laiko ir erdvès suvokimas nepakito nuo antikos laikų. Atstumas, kaip laiko ir erdvès santykio išraiška, ir jo ịveikimo galimybès matuoti žmogaus ir / ar gyvūno raumenu jègos matais. Laiko istorijos pradžiai impulsą suteike, pasak J. Habermaso, „naujojo pasaulio“ atradimas, Renesansas ir Reformacija - tie trys didieji XV a. pabaigos ir XVI a. pradžios ịvykiai, žymėję dviejų epochų - viduramžių ir modernybės - ribą. Laiko išlaisvinimą ir istorinị ịprasminimą J. Habermasas aiškina remdamasis G. W. F. Hegelio ir F. W. J. Schellingo „naujujų laikų“ sampratos pagrindimo perspektyva. Skiriami du laiko, kaip istorijos mato, skaičiavimo metodai:

- krikščioniškoji istorijos filosofijos tradicija;

- pasaulietinis „naujųjų laikų“ diskursas.

Pastarujų dviejų vienos visuomenès socialinės sąveikos vertybinių kontekstų susidūrimas inspiruoja kokybiškai naujos laiko sampratos, kartu ir modernybès, formavimąsi. Laiko sampratos kito kartu su pasaulietinio diskurso sklaida filosofijoje. Krikščioniškojoje Vakarų tradicijoje „naujieji laikai“ traktuoti kaip laikas, prasidèsiantis po paskutinio teismo dienos. Krikščioniškosios socialinès praktikos doktrinos krizė sudarė „naujujų laikų“ chronologinès reikšmės niveliavimo prielaidas. Pasaulietine „,naujųjų laikų“ samprata lemia ịsitikinimą, kad ateitis jau prasidejjo. J. Habermasas čia remiasi F. W. J. Schellingo interpretacija, kai turima galvoje epocha, gyvenanti ị ateitị ir atsivèrusi viskam, kas bus nauja (Habermas, 2002, p. 14).

Modernybès filosofinè tradicija formuojasi kaip istorinès sąmonès kaitos produktas. Istorinè sąmonė igyja gebèjimą save reflektuoti ịsivaizduojant savo pačios istorinę-filosofinę padètį / vietą. Laikas imamas suvokti ne tik kaip atsivėręs atei- 
čiai, bet ir kaip ribotas kylančių problemų sprendimo išteklius. Laikas, t. y. laiku matuojama dabartis, igauna prasmę kaip dinamiškas - nuolat kuriantis ateitị ir akimirksniu nugrimztantis i praeiti - procesas. Modernaus laiko pajauta: istorija (modernybės istorijos pradžia) kartojasi ir įsitvirtina kiekvieną dabarties, gimdančios nauja, akimirką (Ten pat, p. 15).

J. Habermasas laiko aktualizavimo klausimą nagrinèja remdamasis istorijos filosofijos perspektyva, atskleisdamas pačios istorinès sąmonès kaitos kontekstą. Z. Baumanas laiką, kaip ir kitus socialinius reiškinius, analizuoja remdamasis socialine praktika, o jo indukcinius apibendrinimus galima priskirti praktinès filosofijos sričiai.

Z. Baumanas filosofijos tradicijos ir socialinès sąmonès kaitos priežastinius ryšius aiškina technologine kaita. Aiškindamas laiko suvokimo modernybès filosofinị diskursą jis pateikia tokius teiginius:

1. Kartu su modernybe prasideda laiko istorija. Ikimoderniame socialinèsfilosofinès sąmonès vystymosi etape laikas suvoktas kaip objektyvus (pozityvistinis) reiškinys, susaistytas su žmogų ribojusia ir bauginusia sąvokų čia ir ten dialektika. Atstumo įveikimas buvo neatsiejamas nuo žmogaus ir / ar gyvūno fizinių galių ribotumo. Graikų olimpiadų laikais, kaip pastebi Z. Baumanas, nesvarstyta apie olimpinius rekordus. Kad kiltų tokių idèjų, reikejjo atrasti ir išvystyti kitą nei žmogaus ar gyvūno jègą. Technologijų tobulëjimas, paskatintas greičiausiai J. Habermaso minètų didžiujų XV a. pabaigos - XVI a. pradžios ịvykių, sukūrẻ variklį, kuris sukẻlè revoliuciją suvokiant laiką ir erdvę.

2. Nors modernybės eros pradžia siejama su daugybe žmonių veiklos pokyčių, laiko išlaisvinimas iš erdvès apribojimų ir pavaldumas žmogaus valiai bei technologinèms galimybèms yra vienodai reikšminga modernybės gimimo prielaida. Ikimoderniojoje epochoje laiko ir erdvès santykis buvęs statiškas, bet reikšmingų technologinių atradimų dèka jis tampa dinamiškas ir nepastovus. Kita vertus, laiko išlaisvinimas suteikè vertę erdvei. Erdvė tapo viena didžiausių moderniosios epochos vertybių, jos „užkariavimas“ reiškẻ greitesnių mašinų kūrimą. Greitėjantis judèjimo tempas - tai didesnès erdvinès ekspansijos galimybès, kai tempo didinimas traktuojamas kaip vienintele ekspansijos priemonè. Šiame „persekiojime“ erdvinè ekspansija buvo žaidimo esmè, o pati erdvé - prizas; erdvė laikyta vertybe, o laikas - priemone (Bauman, 2000, p. 112-113).

3. Laiko sudaiktinimas paverte ji rutina. Laiko rutinizavimas palaike fordizmo suformuotas darbo etikos nuostatas, taip pat ir erdvès vientisumo, kompaktiškumo, pavaldumo homogeniškumo logikai praktiką. Tai tapo darbo etikos krizès prielaida. 
Modernybès filosofinio diskurso suformuotas istorinis laiko suvokimas sudarè prielaidas J. Habermasui periodizuoti naujuosius - moderniuosius - laikus. Istorinė perspektyva modernybès sampratą padaro neįmanomą, neišskyrus naujuosiuose laikuose „naujausiujų“ - dabartis, kaip naujųjų amžių istorijos naujausias laikas, užima reikšmingą vietą. Dabartis, suvokianti save „naujųjų laikų horizonto pagrindu kaip naujausio laiko aktualybę", atsisveikinimą su praeitimi turi suprasti kaip nenutrūkstamą atsinaujinimą (Habermas, 2002, p. 15). G. W. F. Hegelio laiko periodizavimo metodas, kuriuo J. Habermasas remiasi istorinès filosofijos diskurse, sudaro realias postmodernybès filosofinès tradicijos gimimo galimybes. Tačiau hėgeliškasis laiko skaičiavimo modelis postmodernybę, kaip naujausių laikų filosofinį diskursą, padaro galimą tik kaip paskutinị modernybės raidos etapą.

Laiko socialinè-egzistencinè reikšmė J. Habermaso istorinejje filosofijoje išlieka aktuali. Tuo tarpu modernybès kaitos ir kokybiškai naujos filosofinès tradicijos gimimo aiškinimas Z. Baumano socialinèje teorijoje, kuri akcentuoja technologiju kaitos pasekmes, „laikas / erdvè susitraukia“; galiausiai laikas, kaip priemonè, visiškai niveliuojasi, o erdvè - praranda savo vertę (Bauman, 2000; 2002).

Plètoti savo teorinį diskursą Z. Baumanas pradeda nuo „laiko / erdvès susitraukimo“ ir pritaikymo šiandienos socialiniame gyvenime vykstantiems procesams aiškinti. Sąvoka laiko / erdvès susitraukimas apima nuolatinị įvairialypi žmogaus būvio parametrų kitimą. Šią sąvoką mąstytojas pritaiko globalizacijai - vienai iš postmodernybės operacionalizuotų formų apibūdinti.

„Sunkiojoje modernybeje“ laiko ir erdvès suvokimo ribos garantavo homogeniškos, vientisos erdvès palaikymą, o technologiniam atstumų panaikinimui tradicinis socialinis teritorinis bendrumas nebūdingas. Pasaulinio internetinio tinklo (www) sukūrimas, viršgarsinių mašinų ir palydovinio ryšio žiniasklaidos sukurtam produktui perduoti panaudojimas sukuria tai, ką Z. Baumanas ịvardija kaip „lengvosios modernybès“, arba postmodernybès, sociokultūrinių pokyčių padarinius. Atstumas, kaip socialinis reiškinys, praranda aktualumą. Mobilumas tampa galingiausiu ir geidžiamiausiu socialinių santykių veiksniu. Jis tampa žaliava, iš kurios kasdien kuriamos ir perkuriamos naujos, vis pasaulietiškesnès socialinès, ekonominès ir kultūrinès bendrabūvio formos.

Z. Baumano socialinejje teorijoje formuojamas kokybiškai naujo teorinio diskurso tapsmas. Reikia pastebėti, kad čia nagrinèjamuose darbuose Z. Baumanas retai vartoja postmodernybès sąvoką. Mąstytojas pastaruosiuose darbuose suformuluoja naują - lakios modernybès - sąvoką, kuri atskleidžia tiek technologinio, tiek „laiko / erdvès susitraukimo“ veiksnių svarbą dabarties socialinès sąmonès ir visuomenès bendrabūvio formų kaitai. Tačiau šis terminas nepašalina ir modernybès tęstinumo galimybès $\mathrm{Z}$. Baumano socialinèje teorijoje. 
Atstumų ir vietos traukos įveikimo galimybių vystymasis koreguoja ir kitų socialinių reiškinių vertybinius kontekstus. Laikas ir darbas iš pirmo žvilgsnio - nelabai tarpusavyje susiję terminai, tačiau istorijos filosofijoje, apžvelgiant jų suvokimo raidą, galima įžvelgti paralelinį ryšị. J. Habermaso ir Z. Baumano socialinèse teorijose tokị sąlyčio momentą taip pat galima užčiuopti.

\subsection{Darbo, kaip socialinės vertybės, sampratos kaita}

Šiuolaikiniame pasaulyje skursta ir dirbantys žmonès. Po dramatiškų struktūrinių pokyčių darbo rinkoje pasikeitė užimtumo galimybès, kai nuolatinį užimtumą pakeitė nuolatinis judejjimas $i \check{s}$ ir $j$ darbo rinką, mokymo iniciatyvos, savanoriškas darbas, neformali veikla ir nedarbas (Gershuny, Marsh, 1993; Devine, Savage, 2000). Šiandien aktualu išskirti vargstančių darbuotojų (angl. working poor) kategoriją: dabar naujos darbo vietos kuriamos nesaugiame, mažai apmokamame paslaugų sektoriuje. Kaip pastebi K. Newman (1999), atlikusi etnografinị vargstančių darbuotojų tyrimą skurdžiausiame Vakarų didmiesčio rajone, skurdus darbas profesinès karjeros pradžioje nebèra tiltas ị nuolatinį užimtumą, o karjeros galimybės yra ribotos (ten pat, cituota: Devine, Savage, 2000, p. 191). J. Paluckienė (1999) pasitelkia socialiai kritinių grupių koncepciją. Ji, kaip ir K. Newman (1999), pastebi, kad tam tikros socialinès grupès, tokios kaip 16-25 metu jaunimas, moterys, pensinio ir priešpensinio amžiaus žmonès, labiau izoliuotos darbo rinkoje ir mažiau savarankiškos priimant lemiamus sprendimus savo darbiniame kelyje. Būtent šių socialinių grupių atstovai dirba mažiau apmokamus darbus, blogesnèmis sąlygomis, menkesnès jų galimybės siekti karjeros (Paluckienè, 1999, p. 116).

Darbas, be jokios abejonès, - vienas svarbiausių socialinio patyrimo evoliucijos, kurią atskleidžia socialinių vertybių sistemos raida, veiksnių. Darbo socialinis-vertybinis turinys tapo svarbiausiu modernybès teorinių diskursų plètojimo šaltiniu, kuris suteikè formą ir tęstinumą moderniesiems / naujiesiems laikams. Darbo ontinès charakteristikos nubrèžè svarbią modernybès socialinès-filosofinès tradicijos plètojimo kryptị ir iškèlè tikslą: pavergti, ịkinkyti ir kolonizuoti ateitị, kad chaosą keistų tvarka, atsitiktinumą - nuspejjama (taigi ir valdoma) įvykių seka (Bauman, 2000, p. 136-137). Modernybès epochoje darbas lèmė kokybinius socialinio gyvenimo pokyčius (ryškus skurdo / vargo sumažèjimas, kt.), tačiau svarbiausi jo „nuopelnai“ yra (tariamas) tvarkos užtikrinimas ir istorinio akto, kuriuo socialiniame gyvenime pašalintas fatalizmo momentas, bei žmonių, kaip ypatingos rūšies, ịgalinimas patiems spręsti savo likimą, inspiravimas.

Darbo problemą J. Habermaso ir Z. Baumano socialinèse teorijose būtų galima nagrinèti periodizavus modernybès filosofinès tradicijos vystymąsi darbo-suverenumo dialektikos spektre: 
1 etapas - darbo vertybès dominavimas;

2 etapas - darbo etikos kvestionavimas, suverenumo, kaip gyvenimo būdo alternatyvos, iškilimas;

3 etapas - darbo etikos krizè, vartotojų visuomenès vertybių sklaida.

Darbas, tapęs vienu svarbiausių moderniujų laikų socialinių santykių rodiklių, gausios socialinių mokslininkų bendruomenès (nuo K. Marxo iki šiandienos postmodernistu, taip pat ir Z. Baumano, J. Habermaso) vertinamas prieštaringai - kaip suvaidinęs nevienareikšmi vaidmeni žmonijos vystymosi procese. Nors šiame straipsnyje nagrinèjamame veikale „Modernybès filosofinis diskursas“ J. Habermasas darbo temai skiria gerokai mažiau dèmesio nei kituose savo kūriniuose („Knowledge and Human Interests, 1972; „Theory and Practice“, 1974, kt.), darbo problemą autorius aptaria G. Bataille bendrosios ekonomikos analizės aspektu. Ši perspektyva šiek tiek nutolina J. Habermasą nuo K. Marxo kapitalistinio darbogamybinių santykių-ekonomikos sąveikos vystymo modernybės epochoje, tačiau toliau tęsia marksizmui būdingą moderniujų kapitalizmo vertybių kritiką. Plètodamas kapitalizmo kritiką, J. Habermasas, kaip ir G. Bataille, modernybę regi ịterptą i proto istoriją, kur viena su kita kovoja suverenumo ir darbo jègos (Habermas, 2002, p. 245). Suverenumas išreiškia žmogaus, kaip socialinio individo, teisę rinktis gyvenimo būdą, nebūtinai paremtą modernybès vertybių, taigi darbo, darbinių santykių sistema. Suverenumo ir darbo kovos idèją Z. Baumanas plètojo daugelyje savo veikalų, taip pat ir šiame straipsnyje analizuojamuose darbuose. Darbo, kaip socialinès vertybès, dominavimą prieš kitas socialinio bendrabūvio formas jis ìvardija darbo etikos sąvoka. Šio fenomeno socialinị vaidmenį Z. Baumanas komentuoja šiomis modernybės epochoje vyravusiomis vertybinèmis nuostatomis:

- norėdamas išgyventi ir būti laimingas žmogus turi daryti tai, kas kitiems atrodo naudinga, ir yra vertas būti ịkainotas; niekas neduodama veltui: pirma pačiam reikia duoti, kad vèliau būtu atlyginta;

- darbas, kaip toks, yra vertybè, kilnus ir taurinantis užsièmimas, todèl modernybès epochoje yra nepriimtina demoralizuojanti pasitenkinimo sukurtu gèriu nuostata; taigi dirbti yra gerai, tuo tarpu nedirbti - nuodèmé;

- tokios socialinės praktikos išvada akivaizdi - absoliuti dauguma žmonių parduoda savo darbo jẻgą, kad apmokètų gyvenimo išlaidas ir gautų tai, ko nusipelno. Visa, ką jie turi, yra atlygis už jų ankstesnį darbą ir pasiryžimą toliau dirbti;

- $\quad$ kaip vertingas pripažįstamas tik toks darbas, už kuri gaunamos pajamos ar atlyginimas - kuris parduodamas ir gali būti perkamas, taigi darbas, kuris, darbo etikos požiūriu, turi moralinę vertę (Bauman, 2001, p. 5-6). 
Taip galima būtų apibūdinti istorinį darbo etikos formavimosi turinị, kuris istorinèje filosofijoje ịsilieja ị bendrą modernybès sampratą. Kapitalistiniame modernios industrinès visuomenès raidos etape darbas vienu metu buvo asmeninio gyvenimo, socialinès tvarkos ir visuomenès, kaip tokios, gebejjimo išgyventi šerdis. Jis suvoktas kaip svarbiausias žmogaus visapusiško vertinimo atskaitos taškas, lyginant su kuriuo visi kiti gyvenimo siekiai buvo suplanuoti ir nulemti. Darbas, kurị dirbo individas, lèmé tiek esamą jo socialinę padètị - statusą visuomenèje, tiek ir socialinio mobilumo perspektyvas, taip pat ir savęs vertinimo socialinėje bendruomenèje nuostatas. Darbo pobūdis nulèmé gyvenimo standartus, kurių atitinkamas visuomenès narys galejo tikètis ir kuriems turejjo paklusti. Štai ką turi galvoje K. Marxas, G. Bataille, J. Habermasas, kt. marksistinès tradicijos sekejjai (ir nemažai kritikų postmodernistų), kritikuodami modernybés puoselëjamas darbo etikos vertybes, kurios uzurpavo asmeninio pasirinkimo - suverenumo teisès išraiškos - galimybę. Darbo etika kvietė rinktis gyvenimą, pašvęstą darbui, bet toks gyvenimas reiškė pasirinkimo nebuvimą, jo neprieinamumą ir galiausiai jo uždraudimą (Bauman, 2001, p. 19). Tokių vertybinių nuostatų palaikymo reikèjo ankstesniame skyriuje nagrinèto modernybės tikslo - erdvės užkariavimo - priemonèms kurti ir gamybai užtikrinti.

Užtikrinti, kad bus laikomasi suverenumo principo modernybės laikotarpiu, buvo neįmanoma dar bent dèl kelių kitų priežasčių:

- Dèl ekstensyvaus darbo pobūdžio industrinèje visuomenèje modernybès filosofine tradicija dar vadinama kolektyvinès socialinès sąmonès puoselètoja. XIX a. viduryje, kai darbe buvo praleidžiama, remiantis kai kuriais skaičiavimais, iki 70 proc. darbingo amžiaus, darbo vieta buvo bene svarbiausia socialinès integracijos institucija. Fabrikas buvo dar vienas iš didžiujų modernybės išradimų - „panoptinès institucijos“ - pavyzdžių, kuriuos vèliau išplètojo daugelis postmodernių mąstytojų. Tai pagrindinė erdvè, kurioje buvo mokomasi paklusimo normoms, drausmingo elgesio ịpročių ir ugdomi adekvatūs socialiniai ịūdžiai.

- Kolektyvinę socialinę sąmonę modernybès laikais palaikè pats gamybos procesas: gèrybių kūrimo pobūdis, socialinę ir technologinę pažangą nulèmusio darbo pasidalijimo principo taikymas. Siaura monofunkcinė darbo specializacija - fordizmo puoselëjama idejja - padarẻ darbininkus priklausomus vienus nuo kitų ir nuo darbo ịrankiu (gamyklos / fabriko staklių, kt.) bei garantavo kolektyvizmo vertybinès nuostatos sklaidą. Tokie stambūs kolektyviniai vienetai, tokie kaip fabrikai ir gamyklos, kartu padejo maksimaliai išplèsti homogeniškumo principo igyvendinimą modernioje epochoje. Marksistų ir kitų šiuolaikinių mąstytojų požiūriu, tai taip pat socialinès kritikos vertas modernybės vystymo aspektas. 
- Tokias išvadas J. Habermasas, Z. Baumanas ir kiti jų amžininkai daro iš istorinès modernybès raidos ir postmodernybès vertybinių normų formavimosi perspektyvos. Jie pripažista, kad tokia socialinių normų praktika buvo nulemta tuo metu dominavusio laiko ir erdvès vertybinio turinio. Kapitalistinejje visuomeneje pirmiausia veikia abstrakčiai laiku ir pinigais matuojamas darbas, kaip homogenizuojanti jèga, kuri, susieta su mokslu ir technika, nuolat didejja. Modernybeje dominavusi darbo etika buvo pavergusi ne tik darbininkus, parduodančius savo darbo jègą ${ }^{1}$, bet ir savininkus, kurių modernybės siūlomiems tikslams ịgyvendinti darbo jègos pirkimas buvo neišvengiamas. Vartojant Z . Baumano terminus, darbo jèga, atstovaujanti darbininkams, ir darbo priemonès, valdomos savininkų, buvo sujungtos į amžiną sajungą ir patvirtintos laiko ir erdvès įveikimo, bet ne jų ìvaldymo sukeltų apribojimų (Bauman, 2000).

Modernybės filosofinès tradicijos posūkị darbo-suverenumo kontekste galima fiksuoti tada, kai suformuluojama suverenumo, kaip darbui alternatyvaus gyvenimo būdo, idèja. Šios idejjos užuomazgų galima atrasti K. Marxo ir jo sekejjų filosofinèse nuostatose. J. Habermasas „Modernybès filosofiniame diskurse“ remiasi ir palaiko G. Bataille sukurtoje suverenumo koncepcijoje išplettotas K. Marxo² teorines figūras. Šio XX a. „komunisto“ ${ }^{\text {“3 }}$ suverenumo teorija J. Habermaso vertinama kaip sudaiktejjimo teorijos, kurią M. Weberio marksizmo pagrindu išplètojo G. Lukácsas, M. Horkheimeris ir T. W. Adorno, priešingybė. Suverenumo teorinèje koncepcijoje kurdamas ekspresyvistinị žmogaus veiklos modelį, G. Bataille paneigia tariamai akivaizdžią modernybès išvadą, kad „gyvenimas“, dẻl kurio yra gaminama, glūdi pačiame darbe. Darbas, kaip vienintelis teisingas gyvenimo būdo pasirinkimas, padedantis žmogui visapusiškai save realizuoti, kvestionuojamas: iškeliama neproduktyvaus vartojimo idejja, kuri pavienio prekių gamintojo požiūriu būdama nuostolinga, gali suteikti žmogui suverenumo ir patvirtinti jo autentišką egzistavimą (Habermas, 2002, p. 253). Plètodamas neproduktyvaus vartojimo ideją, J. Habermasas toliau vadovaujasi G. Battaile teorinemmis nuostatomis, kur formuluojama mintis, kad tik švaistydamas vartojantis subjektas gali išreikšti save, taigi ir būti suverenus, t. y. neleisti savęs nužeminti iki daikto, kaip yra moderny-

1 Čia tiek J. Habermasas, tiek Z. Baumanas operuoja teorinèmis mąstymo figūromis ir visą „kaltę“ verčia, K. Marxo terminais kalbant, „didžiajai transformacijai“, kurios esmè - darbo jègos ir darbo priemonių atskyrimas.

2 K. Marxas kalba apie laisvę anapus būtinumo, anapus medžiagų apykaitos su gamta determinuotos gamybos srities, $\mathfrak{i}$ individualų jègų eksternacijos ir kartotinio savinimosi modelị įtraukdamas dar ir kūrybišką laisvalaikio leidimą. Kaip atskaitos taškas K. Marxo filosofijoje imamas absoliutus, pats save universaliai realizuojantis individas.

3 Taip G. Bataille apibūdina J. Habermasas „Modernybės filosofiniame diskurse“. 
bės puoselëjamoje darbo etikoje, bet išlaisvinti subjektyvume. Tačiau pripažịstama, kad modernioje sistemoje, kur dominuoja kapitalizmo vertybès, sukuriamas perteklius vèl panaudojamas gamybai, o ne beprasmiškam vartojimui, suverenumas yra pasmerktas: suvereni būtybė moderniose visuomenèse sudvasinama ir eliminuojama iš visuotinybės, kur viskas tarnauja privačiai nuosavybei, kurią sudaro vien tik daiktai (Habermas, 2002, p. 255).

Neproduktyvus vartojimas - su gamyba nesusijusios išlaidos - tik klasikinio kapitalizmo modernybès laikotarpiu galèjo būti neigiamai apibūdinamas vartojant švaistymo sąvoką. Vèlyvosios, lakios modernybès, arba postmodernybès, tapsmo kontekste neproduktyvus vartojimas praranda savo ydingaji turinị. Darbo etika užleidžia avansceną vertybinėms vartojimo nuostatoms. Z. Baumanas vartotojiškos visuomenès idejją plètoja savo paskutiniuose darbuose, tarp kurių yra ir čia analizuojami „Work, Consumerism and the New Poor“, „Globalizacija: pasekmès žmogui“. Neneigdamas, kad gyvenimas mūsų visuomeneje (,mūsų visuomene“ jis vadina lakios modernybès, vèlyvosios modernybès [remiantis A. Giddens], antrosios modernybės [remiantis U. Becku], viršmodernybės [remiantis G. Balandier] ar postmodernybès laikotarpị) ir mūsų pirmtakų visuomenèje (tai reikètų suprasti kaip užuominą į modernybės klestẻjimo erą) nèra tokie jau skirtingi dalykai ${ }^{4}$, kad dvi modernybès stadijos skiriasi „tik“ akcentais ir prioritetais, vis dèlto pabrèžia, kad pasikeitę akcentai nulèmè didžiulius skirtumus iš esmès visose visuomenès, kultūros ir individualaus gyvenimo plotmèse (Bauman, 2002, p. 123-124). Naujai modernybės epochai jis priskiria tokius bruožus:

- Mūsų visuomenę Z. Baumanas apibūdina kaip vartotojų visuomenę, pašalinęs iš šios sąvokos modernybès epochoje klestējusios darbo etikos sukurtą ribojantiji jos aspektą. Vartotojų visuomenès sąvokai jis suteikia visą anksčiau darbo etikai priklausiusị socialinį-etinị turinị: mūsų visuomenė yra „vartotojų visuomenė“ ta prasme, kokia mūsų pirmtakų modernioji visuomenė buvo ,gamintojų visuomené“. Moderniosios visuomenės vertybinès nuostatos sutelkè savo narius pirmiausia kaip gamintojus, tuo tarpu postmoderniai visuomenei, talpinančiai technologinio, sociokultūrinio, ekonominio ir kitos pažangos sukurtą gyvenimo kokybę, jau mažai bereikia masinio industrinio darbo. Vietoj to, ji telkia savo narius kaip vartotojus. Būdą, kaip šių dienų visuomenè formuoja savo narius, pirmiausia nulemia pareiga atlikti vartotojo vaidmenị (Bauman, 2001, p. 24).

- Individualizmas yra postmodernios visuomenès produktas ir norma. Jị skatina vartotojų visuomenès normos ir taisyklès. Vartojimas, skirtingai

4 Čia Z. Baumanas turi mintyje nenuginčijamą faktą, kad nei buvusiu, nei dabartiniu modernybès laikotarpiu visuomenè negali negaminti vartojimui skirtų daiktų, savaime aišku, kad abiejų visuomenių nariai vartoja (Bauman, 2001; 2002; 2000). 
nuo gamybos, iš esmès yra individuali, pavienè ir galiausiai vieniša veikla; veikla, kuri pripildyta norų, visada tokių privačių, malšinimo ir sužadinimo, nuraminimo ir sukèlimo. Nèra tokio dalyko, kaip „kolektyvinis vartojimas“ (Ten pat, p. 30). Žinoma, vartojimui skirta erdvė yra vieša, ir visuomenès nariai - tikrieji vartotojai - yra pamėgę tas pačias vietas, tačiau net tada vartojimas išlieka išskirtinai vienišas, individualistinis asmens patyrimas. Vartotojai yra vieni, net jeigu jie veikia kartu. Z. Baumano suformuota vartojimo vertybinè nuostata radikalizuoja J. Habermaso eskaluojamą suverenumo sąvoką, pabrèždama vertybinių prioritetų persiskirstymą darbo-suverenumo dialektikoje. Socialinejje praktikoje besiformuojanti atsinaujinusi vertybių sistema nelieka nepastebèta filosofiniame kontekste: vieniems mąstytojams tai „tik“ naujas modernybès etapas, kitiems - tai naujos filosofinès tradicijos formavimosi prielaidos.

Darbo-suverenumo dialektikos analizė aiškinant postmodernybès tapsmą pirmiausia leidžia atskleisti patị modernybès filosofinio diskurso raidos procesą. J. Habermasas ir Z. Baumanas šiuo atveju savo teorinėmis nuostatomis puikiai papildo vienas kitą. Laipsniškas darbo vertybès keitimas suverenumo vertybine nuostata patvirtina, kad postmodernybès tapsmas yra tipiška socialinio patyrimo sukurta priežastis ir pasekmè. Postmodernybès filosofinès tradicijos užgimimas yra modernybės sukurtų vertybių neigimas.

\section{Išvados}

J. Habermaso ir Z. Baumano socialinių teorijų analizė leidžia daryti tokius apibendrinimus:

1. J. Habermaso ir Z. Baumano socialinès teorijos tik iš pirmo žvilgsnio atrodo visiškai skirtingos. Atlikus išsamesnę jų analizę, atsiskleidžia jų filosofinių figūrų panašumas, be to, gvildenamos tos pačios modernybès temos. Pirminè skirtumų priežastis šių mąstytojų teoriniuose diskursuose yra pasirinktos skirtingos postmodernybès tapsmo aiškinimo išeities pozicijos. J. Habermasas postmodernybès filosofinès kokybės ieško modernioje teorineje ir intelektinejje patirtyje. Tuo tarpu Z. Baumano teorinès minties plètojimo metodika sudaro ịspūdị, kad būtent modernybę jis vertina iš postmodernios perspektyvos.

2. Kalbant apie postmodernybès filosofinio diskurso tapsmo prielaidų aiškinimą J. Habermaso ir Z. Baumano socialinèse teorijose, abu mąstytojai postmodernybės tapsmo aiškinimą grindžia istorine perspektyva ir modernybės savivokos prielaidomis, tačiau jų teorijų plètojimo kryptys išsiski- 
ria: J. Habermasas postmodernybę konstruoja (tik) kaip naują modernybės filosofinès tradicijos raidos etapą. Z. Baumanas, neneigdamas, kad gyvenimas mūsų visuomenèje ir mūsų pirmtakų visuomenejje nèra tokie jau skirtingi dalykai, kad dvi modernybès stadijos skiriasi „tik“ akcentais ir prioritetais, pabrěžia, jog pasikeitę akcentai vis dèlto lèmé didelius pokyčius beveik visose visuomenès gyvenimo srityse. Nors modernybės tęstinumo galimybès Z. Baumano socialinejje teorijoje tai nepanaikina.

3. Modernybès raidos ir postmodernybès tapsmo aiškinimas ịgauna prasmę atliekant konkrečių tyrimo aspektų analizę. Postmodernybès tapsmo prielaidoms paaiškinti palanki strategija - iš naujo ịvertinti modernybeje svarbius socialinès savimonès rodiklius, tokius kaip laiko ir darbo suvokimas.

Analizuojant laiko sampratą, J. Habermaso ir Z. Baumano taikoma socialinės patirties periodizavimo metodika atskleidžia tam tikrą lūžį modernybès filosofiniame diskurse, atsirandantị modernybès tapsmo metu.

Darbas, kaip socialinė vertybè, aktualizuojamas darbo-suverenumo dialektiniame prieštaravime. J. Habermaso ir Z. Baumano socialinèse teorijose postmodernybès tapsmas grindžiamas vertybinès pusiausvyros dinamika darbo-suverenumo dialektiniame spektre: nuo darbo etikos dominavimo iki optimalaus suverenumo igyvendinimo vartotojų visuomeneje.

4. Atstumų ịveikimo galimybių sudarymas ir darbo, kaip socialinės integracijos terpès, reikšmès mažèjimas bei pasikeitimas koreguoja ir kitus socialinio bendrabūvio kontekstus: individualizmo iškilimą ir racionalizmo turinio kaitą.

Gauta 20140812

Pasirašyta spaudai 20140929

\section{Literatūra}

Bauman, Z. (2000). Liquid Modernity. Malden: Blackwell Publisher Ltd.

Bauman, Z. (2001). Work, Consumerism and the New Poor. GB: Bibbles Ltd.

Bauman, Z. (2002). Globalizacija: pasekmès žmogui. Vilnius: Strofa.

Devine, F., Savage, M. (2000). Conclusion: renewing class analysis. In: R. Crompton, F. Devine, M. Savage, J. Scott Renewing Class Analysis (eds.). Oxford: Blackwell.

Gershuny, J., Marsh, C. (1993). Unemployment in Work Histories. In: D. Gallie, C. March, C. Vogler. Social Change and the Experience of Unemployment (eds.). Oxford: Oxford Univeristy Press.

Habermas, J. (2002). Modernybès filosofinis diskursas. Vilnius: Alma littera.

Paluckienė, J. (1999). Socialiai kritinès grupès kuriant gerovės valstybę. Kn.: A. Česnavičius, A. Dargytė-Burokienė, I. Gečienė, I. Gudaitienė, J. Paluckienė, M. Taljūnaitè. Socialinis struktūralizmas ir jo pažinimas. Vilnius: Lietuvos filosofijos ir sociologijos institutas.

United Nations Organization. (2014). Human Development Report 2014. Prieiga internete: http://hdr.undp.org/ sites/default/files/hdr14-report-en-1.pdf [žiūrèta 2014-09-23].

Urbonaitė-Vainienè, I. (2014). Plinta naujos skurdo formos: pasitikrink, ar nesi vargšas. Prieiga internete: http:// www.delfi.lt/news/daily/lithuania/plinta-naujos-skurdo-formos.d?id=64545274 [žiūrèta 2014-04-21]. 


\section{DISCOURSE OF ATTITUDE TO TIME AND WORK IN THE WORKS OF J. HABERMAS AND Z. BAUMAN}

\section{Sonata Mačiulskytè}

\section{Summary}

Legitimation of postmodernity is one of the objects of todays' endless intellectual debates. A favourable strategy to explain the assumptions of postmodernity formation is to re-assess the indicators of social awareness which are important in the modernity, such as time and work perception.

Social phenomena of time and work are among elements of social-existential change, which reflect clear differences of a philosophical discourse and social consciousness of modernity from the earlier traditions of philosophical thought development. Modernity, undoubtedly, meant a qualitatively new philosophical conception, inspired by the intellectual, technological, material, etc. potential created by a comprehensive social experience.

As regards the formation of postmodernity, its interpretation makes sense when we have a limited sample of research aspects. The choice of scholars, whose works are used as a basis for a comparative analysis of the development of the values of work and time, was not accidental, and therefore rather challenging for the article. There are both differences and similarities between the strategies of social theory development presented by Jürgenas Habermas and Zygmund Bauman. The analysis of this article is based on the following works: The Philosophical Discourse of Modernity (first published in 1985) by J. Habermas, and Work, Consumerism, and the New Poor (1999), Globalization: the Human Consequences (2000), Liquid Modernity (2000) by Z. Bauman. These works emerged in the context of social realities of the $9^{\text {th }}-10^{\text {th }}$ decades of the $X^{\text {th }}$ century. Both thinkers, then the elite of contemporary social thinkers, are completely different in the development of their intellectual thought. J. Habermas projects his philosophical explanation of reality from the value-based constructs of modernity to a theoretical and intellectual justification of postmodernity. In other words, he is looking for postmodernity in the theoretical and intellectual potential accumulated by modernity. Meanwhile, the theoretical thought of Z. Bauman, on the contrary, is directed in the opposite direction. The main object of his social theory development is explanation of postmodern existences. We may get the impression that he is evaluating modernity from the postmodern perspective. Despite, perhaps, an absolute difference between their theoretical thought development, both of them pay a lot of attention to 
the explanation of time and work concepts (development), allowing to trace the construction of the authors' social theories of modernity and postmodernity.

The aim of this article is to reflect on the tangibility of the formation of postmodernity in the contemporary social theories, with the emphasis on the philosophical explanation of the change in the perception of the social phenomena of time and work in the intellectual thought of J. Habermas and Z. Bauman.

One of the main new forms of social inequality is lack of time. There is no need to starve or to be roofless in order to be recognised as destitute. The analysis of the concept of time shows that J. Habermas and Z. Bauman use the method for periodization of social experience which reflects a certain turning point in the philosophical discourse of modernity, emerging during the period of formation of modernity. Time is a subjective social phenomenon, despite its eternity and objective nature. Time is in a constant state of change, regardless of the will of a person, however, a person managed to master it and to give it a specific social role. In fact, the change of social experience of time is linked to the emergence and development of the era of modernity. Moreover, a new transformation of the social role of the perception of time is experienced in the later stage of the modernity discourse.

Work as a social value is actualised in the dialectical opposition of work and sovereignty. The formation of postmodernity in the social theories of J. Habermas and $\mathrm{Z}$. Bauman is grounded in the value-based equilibrium dynamics in the dialectical spectrum of work and sovereignty: from the dominance of work ethic to the realisation of optimal sovereignty in the consumer society.

After dramatic structural changes in the labour market, the employment opportunities have changed when permanent employment was changed by permanent movement from and to the labour market, as well as by training initiatives, volunteering, non-formal activity, and unemployment. A category of the working poor has emerged: now new workplaces are created in the unsafe and low-paid service sector.

The development of possibilities to overcome distances and a decrease and change in the significance of work as a medium of social integration, consequently adjust other contexts of social coexistence: the emergence of individuality and a change in the content of rationalism. 